\title{
ANALISIS ISTIHSANATAS PERTIMBANGAN HAKIM TERHADAP SAKSI NON MUSLIM PADA PERKARA PERCERAIAN
}

\author{
Ahmad Misbahul Zaman \\ Desa Banjaranyar Kecamatan Tanjunganom Kabupaten Nganjuk. \\ Email: amisbahulzaman@gmail.com
}

\begin{abstract}
Verification in the Religion Court is important because the court upholds law and justice based on no other evidence, including in civil cases, such as divorce. One of the proofs is a witness testimony. The majority of Islamic law experts like Imam Malik, Imam al-Shafi'i or Imam Ahmad ibn Hanbal agreed that a witness must be a Muslim, so that in a case witnessed by someone who is not Muslim, his testimony is deemed invalid. This article wants to see a case of establishing non-Muslim witnesses in a divorce case in the Sidoarjo Religious Court by using descriptive analysis, which is systematically describing the facts and characteristics of the object studied by the later analysis and using the istibsan theory. Based on the analysis, the Sidoarjo Religious Court in Case No. 1889/Pdt.G/2017/PA.Sda. has received the status of a nonMuslim witness because it has fulfilled formal requirements in a civil procedure law. In line with istihsan theory, non-Muslim testimony is permissible because of the development of the present era and its greater difficulties so that it can be accepted in religious courts. If it is forced that witnesses to be Muslim, then justice seekers will be harmed and have difficulties.
\end{abstract}

Keywords: Consideration of judges, non-Muslim witnesses and divorce

\begin{abstract}
Abstrak: Pembuktian di muka peradilan Agama merupakan hal yang penting sebab pengadilan menegakkan hukum dan keadilan tidak lain berdasarkan pembuktian, termasuk dalam perkara perdata, seperti perceraian. Salah satu alat bukti keterangan saksi. Mayoritas para pakar hukum Islambaik Imam Malik, Imam al-Shafi'i ataupun Imam Ahmad ibn Hanbal menyepakati bahwasannya seorang saksi harus beragama Islam, sehingga apabila dalam suatu perkara yang disaksikan oleh orang yang bukan beragama Islam, maka kesaksiannya dipandang tidak sah. Tulisan ingin melihat satu kasus penetapan saksi non-muslim dalam perkara perceraian di Pengadilan Agama Sidoarjo dengan menggunakan analsisi deskriptif, yaitu menggambarkan secara sistematis fakta dan karakteristik objek yang diteliti suntuk kemudian dianalisis mengguanakan teori istihsan. Berdasarkan analisis, Pengadilan Agama Sidoarjo dalam perkara Nomor. 1889/Pdt.G/2017/PA.Sda menerima status saksi non muslim karena sudah memenuhi syarat-syarat formil dalam hukum acara perdata. Sejalan dengan teori istibsan, kesaksian non-muslim diperbolehkan karena melihat perkembangan zaman yang sekarang ini dan lebih besar maslahatnya sehingga bisa diterima di pengadilan agama. Jika memaksakan saksi harus yang beragama Islam, maka para pencari keadilan akan dirugikan dan mengalami kesulitan.
\end{abstract}

AL-HUKAMA

The Indonesian Journal of Islamic Family Law Volume 08, Nomor 02, Desember 2018; ISSN:2089-7480 
Kata Kunci: pertimbangan hakim, saksi non-muslim dan perceraian

\section{Pendahuluan}

Dalam perkara perdata, diperlukan dengan adanya pembuktian. Pembuktian di muka peradilan Agama merupakan hal yang terpenting sebab pengadilan dalam menegakkan hukum dan keadilan, tidak lain berdasarkan pembuktian. Pembuktian memegang peranan yang sangat penting dalam pemeriksaan perkara pada persidangan di pengadilan, karena berperan untuk meyakinkan hakim akan kebenaran peristiwa atau kejadian yang diajukan oleh para pihak yang bersengketa dengan alat-alat bukti yang telah ditetapkan oleh Undang-undang.1

Adapun salah satu alat bukti yang terdapat dalam suatu peradilan adalah keterangan saksi. Pembuktian diperlukan apabila terdapat perselisihan terhadap suatu permasalahan di pengadilan dimana seorang mengaku, bahwa suatu hal tersebut adalah haknya sedangkan pihak lain menyangkal terhadap pengakuan yang dikemukakan oleh orang tersebut.

Saksi adalah orang yang memberikan keterangan di muka sidang, dengan memenuhi syarat-syarat tertentu, tentang suatu peristiwa atau keadaan yang dilihat, apa yang didengar, dan yang ia alami sendiri, sebagai bukti terjadinya peristiwa atau keadaan tersebut. Maka dari itu, Islammenetapkan beberapa syarat saksi sebagai berikut:

1. Beragama Islam(Muslim)

Mayoritas para pakar hukum Islambaik Imam Malik, Imam al-Shafi'i ataupun Imam Ahmad ibn Hanbal menyepakati bahwasannya seorang saksi harus beragama Islam, sehingga apabila dalam suatu perkara yang disaksikan oleh orang yang bukan beragama Islam, maka kesaksiannya dipandang tidak sah, karena tidak mencukupi syarat.2

Imam Abu Hanifah sebenarya memiliki pemahaman yang sama dengan para pakar lainnya, tetapi untuk masalah wasiat

1 Abdul Manan, Penerapan Hukum Acara Perdata di Lingkungan Peradilan Agama, (Jakarta: Prenada Media, 2005), 227.

2 Ibnu Elmi AS Pelu dan Abdul Helim, Konsep Kesaksian "Hukum Acara Perdata di Peradilan Agama Islam”, (Malang: Setara Press, 2015), 15. 
saksi dibolehkan dari non-muslim. Wasiat tersebut disampaikan di tengah perjalanan dan tidak ada orang lain yang dapat dipercaya untuk menjadi saksi wasiat tersebut.3

2. Adil

Dengan sifat adil ini, seorang saksi dapat memberikan keterangan yang berimbang dan tidak memihak kepada salah satu yang berperkara.

3. Baligh, yakni dapat membedakan antara yang benar dan salah serta yang baik dan yang buruk.

4. Berakal, yakni dapat berpikir dan memberikan keterangan dalam keadaan sadar, bukan dalam keadaan maupun gila.

5. Dapat berbicara atau apabila saksi seorang yang bisu, setidaknya saksi mesti dapat menuliskan kesaksiannya.

6. Ingat dengan baik terhadap apa yang pernah disaksikannya dan masih dapat menerangkannya ketika diminta keterangan.

7. Seorang saksi tidak sedang berperkara atau tidak sedang diduga terlibat kasus hukum ataupun kasus etik.4

Berkaitan dengan keberadaan saksi dalam pembuktian, dalam QS. Al-Baqarah ayat 282 tentang kesaksian dijelaskan:

"... Dan persaksikanlah dengan dua orang saksi dari orang-orang lelaki (di antaramu). Jika tidak ada dua orang lelaki, maka (boleh) seorang lelaki dan dua orang perempuan dari saksi-saksi yang kamu ridhai, supaya jika seorang lupa maka yang seorang mengingatkannya. Janganlah saksi-saksi itu enggan (memberi keterangan) apabila mereka dipanggil,,,"5 (QS. Al-Baqarah: 282)

Para ahli Hukum Islamsepakat, bahwa kesaksian orang-orang non-muslim terhadap orang Islamtidak diperkenankan secara mutlak. Mereka berpendapat, bahwa kesaksian itu adalah masalah kekuasaan, sedangkan orang-orang non-muslim tidak berkuasa atas orang-orang muslim.6

3 Ibid., 15.

4 Ibid., 17.

5 Lajnah Pentashihan Mushaf Al-Qur'an, Al-Qur'an Dan Terjemahnya, (Jakarta Selatan: PT. Hati Emas, 2007), 47.

6 Abdul Manan, Penerapan Hukum Acara Perdata di Lingkungan Peradilan Agama, (Jakarta: Prenada Media, 2005), 232. 
Permasalahan tersebut akan coba peneliti kaji melalui salah satu dalil yang sering diperdebatkan penggunaannya dalam khazanah keilmuan Usul al-Fiqh yang mengakomodasi dan mengamini nilai kemampuan secara hukum di masyarakat., yaitu teori istibsan. Teori ini perkenalkan oleh Imam al-Hanafi dan belum pernah dirumuskan oleh ulama sebelumnya meskipun dalam praktiknya sudah pernah dilakukan oleh sahabat 'Umar ibn al-Khattab.7

Istihsan sendiri berasal dari kata dasar Hasana (حسن), artinya baik atau indah,8 Maksunya adalah sesuatu yang dianggap baik dan indah. Istibsan adalah pindahnya seorang mujtahid dari tuntutan qiyas nyata (jali) kepada qiyas samar (khafi), atau dari dalil kully kepada hukum takhshish lantaran adanya dalil yang menyebabkan mujtahid mengalihkan hasil pemikirannya dan mementingkan perpindahan hukum.

Istihsan juga mengakui pengalihan dalil naș yang bersifat umum. Ia berbeda dengan maslahah mursalah-nya Imām al-Malik, tetapi tujuan utamanya adalah tetap menghendaki kebaikan dan kemaslahatan. Perbedaannya hanya soal metode; kalau istibsan menimbang antara dua dalil yang lebih kuat, maka maslahah mursalah adalah menciptakan hukum sama sekali. 9

Berbeda dengan pendapat Imam al-Shafi'i yang tidak sepakat dengan adanya istibsan, ia menolak secara tegas dan berkata, "Barang siapa yang ber-istihsan, maka sesungguhnya dia telah membuat syariat". 10 Tetapi, bukan berarti istibsan tidak dapat dipakai sebagai dalil buijah. Karena alasan inilah, penulis memandang perlu mengkaji penggunaan saksi non-muslim dalam perkara perceraian dengan mengguanakan kacamata istibsan.

Terdapat beberapa kajian yang sama-sama membahas tentang kesaksian non-muslim di Peradilan Agama. Misalnya skripsi berjudul "Pertimbangan Hakim Tentang Kedudukan Saksi Non-Muslim dalam Perkara Perceraian di Pengadilan Agama Kabupaten Bangli Provinsi Bali" (Studi Atas Perkara No. 01/Pdt.G/2006/PA.Bangli). Skripsi ini

7 Yayan Sopyan, Tarikh Tasyri, (Depok: Gramata Publishing, 2010), 133.

8 Muhamad Ma'sum Zainy al-Hasyimiy, Ilmu Ushul Fiqh, cet.1 Jombang: Darul Hikmah, 2008), 106.

9 A. Hanafie, Usul Fiqh, (Jakarta: Widjaya, 1989), 143.

10 Muhammad ibn Idris al-Syāfi'i, al-Um, Juz 7, (Beirut: Dār al-Ma'rifah), 27. 
menggunakan tinjauan hukum Islamdan hukum Positif.11 Penelitian lainnya misalnya yang berjudul; Kesaksian Non Muslim Sebagai Alat Bukti dalam Perkara Perceraian di Pengadilan Agama Boyolali. penelitian ini menjelaskan tentang kesaksian non-muslim sebagai alat bukti perceraian dan menekankan, bahwa keterangan saksi non muslim tidak dapat diterima oleh ahli fikih dan sebagai kalangan imam-imam madzab.

Penelitian lainnya tentang saksi non-muslim berjudul: Status Saksi Non-Muslim di Pengadilan Agama Studi Perbandingan Ibnu Qayyim dan Hukum Acara Perdata. Penelitian ini membahas tentang status non-muslim sebagai saksi di Peradilan Agama dengan mebandingkan pendapat Ibnu Qayyim dan Hukum Acara Perdata.

Hasil dari skripsi ini menunjukkan bahwa diperbolehkannya saksi beda agama tetapi dengan syarat-syarat tertentu yakni dalam masalah wasiat dan perceraian kecuali hal-hal yang berhubungan dengan syari'at agama seperti nikah.12 Contoh lainnya adalah penelitian berjudul Kedudukan Saksi Non Muslim Dalam Praktik. Hukum Acara di Lingkungan Peradilan Agama. Penelitian ini menemukan, bahwa pada dasarnya asas keislaman adalah asas utama yang melekat pada undang-undang peradilan agama yang mempunyai makna, bahwa pihak yang tunduk dan dapat ditundukkan kepada kekuasaan di lingkungan peradilan agama hanya karena yang beragama Islam.13 penelitian lainnya misalnya yang berjudul: Kesaksian Non-Muslim dalam Sidang Peradilan Agama Studi Komparatif Antara Mazbab Hanafi dan Mazhab Syafi'i. penelitian ini menegaskan, bahwa kesaksian non-muslim dapat diterima oleh kalangan manapun, selagi kesaksiannya itu demi mengungkapkan

11 Mohammad Roviqi, Pertimbangan Hakim Tentang Kedudukan Saksi Non Muslim Dalam Perkara Perceraian di Pengadilan Agama Kabupaten Bangli Provinsi Bali. Studi Atas Perkara No. 01/Pdt.G/2006/PA. Bangli. (Skripsi-UIN Maulana Malik Ibrahim, Malang, 2011).

12 Nurfitriani Aziz, Status Saksi Non Muslim di Peradilan Agama Studi Perbandingan Ibnu Qayyim dan Hukum Acara Perdata, (Skripsi-UIN Alauddin, Makassar, 2015). 13 Andi Nur Alamsyah, Kedudukan Saksi Non Muslim Dalam Praktik Hukum Acara di Lingkungan Peradilan Agama, (Skripsi-Universitas Hasanuddin, Makassar, 2014). 
kebenaran sebagaimana nilai-nilai ajaran Islam.14 kajian yang penulis lakukan adalah pengembangan dari kajian-kajian sebelumnya tentang penggunaan saksi non-muslim di Pengadilan Agama yang melihat masalah tersebut mengguanakan kerangka teori istibsan. Teori ini belum pernah digunakan oleh peneliti-peneliti sebelumnya.

\section{Pengertian Istihsan}

Istibsan secara etimologi berasal dari kata dasar Hasana yang artinya baik atau indah, maksudnya adalah sesuatu yang dianggap baik dan indah.15 Sedangkan istihsan sendiri adalah bentuk masdar dari kata kerja istahsana yang artinya menganggap baik sesuatu. 16 Juga dapat dimaknai sebagai memegang teguh sesuatu yang baik dan menolak sesuatu yang bertentangan darinya.

Secara umum, ulama usul berpendapat bahwa istihsan adalah meninggalkan hukum yang telah ditetapkan pada suatu peristiwa atau kejadian yang ditetapkan berdasarkan dalil shara', menuju hukum lain dari peristiwa itu juga, karena ada suatu dalil shara' yang mengharuskan untuk meninggalkannya.17 Pengertian seperti ini masih terlalu singkat dan perlu dijabarkan secara komprehensif.

Untuk itu, peneliti sertakan berbagai pendapat ulama lintas mazhab yang menjelaskan definisi istibsan.

1. Ulama Hanafiyyah berpendapat, bahwa istibsan adalah berpalingnya seorang mujtahid dari suatu hukum pada suatu masalah yang sebanding kepada hukum yang lain, karena ada suatu pertimbangan yang lebih utama menghendaki berpaling. Bukan sekedar menafikan makna tanpa ada dalil yang mendasarinya. 18

14 Ahmad Ro’iat, 'Kesaksian Non Muslim Dalam Sidang Peradilan Agama Studi Komparatif Antara Mazhab Hanafi dan Mazhab Syafi'i', (Skripsi-UIN Sunan Kalijaga, Yogyakarta, 2005).

15 Muhammad Ma'sum Zein, Ilmu Usul Figh, (Jombang: Darul H\{ikmah dan Maktabah al-Syarifah al-Khadijah, 2008), 106.

16 Eka Sakti Habibullah, "Pandangan Imam Abu H\{anifah dan Imam Shafi'i tentang al-Istihsan", Al Mashlahah Jurnal Hukum dan Pranata Sosial Islam, 453.

17 Sharifuddin, "istihsan dan Pembaharuan Hukum Islam", Tabkim vol. X No. 2, Desember 2014, 56.

18 Sharifuddin, Tabkim vol. X No. 2., ..., 56. 
2. Mazhab Maliki mengatakan, bahwa istihsan adalah berpegang kepada kemaslahatan khusus dalam berhadapan dengan dalil umum.

3. Mazhab Hanbali mengatakan, bahwa istihsan adalah menyimpang dari ketentuan suatu masalah yang bersifat khusus.19

4. Mazhab al-Shafi'i mengatakan, bahwa istihsan ialah cara istimbat hukum dengan hawa nafsu dan mencari enaknya.2o

\section{Ke-Hujjah-an Istihsan}

Istibsan merupakan dalil yang menjadi perselisihan dalam kalangan para ulama ușul fiqh. Sebagian ulama, meletakkan istibsan sebagai salah satu dalil penting yang perlu digunakan sebagai sumber hukum islam.21 Sebagian ulama lain menafikan penggunaan istibsan dalam penentuan hukum shara'.

Terdapat perbedaan pendapat antara ulama ușul fiqh dalam menetapkan istibsan sebagai salah satu metode atau dalil untuk menetapkan hukum shara', menurut ulama Hanafiyyah, Malikiyyah, dan sebagian Hanbaliah, istibsan merupakan dalil yang kuat dalam menetapkan hukum shara' (bujjah shar'iyyah). Istibsan bukanlah pendapat yang semata-mata berdasarkan hawa nafsu atau selera belaka dan juga bukan sekedar pencermatan tanpa dalil. Melainkan mereka itu mengacu pada karakter shari'at Islamadalah meninggalkan kesukaran dan mengambil kemudahan.22

Dikutip Ubaidillah \& Nawawi dalam artikelnya Tinjanan Istibsan terhadap Bai' al-Wafa' dan Implikasi Konsistensi Bermadz̧hab di Baitul Maal Wa Tamwil Sidogiri Cabang Bondowoso", jurnal Istidlal, Wahhab Hallaf mengatakan: "istihsan bukanlah sumber hukum yang independen, karena diktum hukum yang pertama termasuk dua macam hukum itu juga, yang dalilnya melalui konsep qiyas khafi yang memenangkan konsep qiyas jaly". Sementara para ulama diam akan

19 Sharifuddin, Tabkim vol. X No. 2., ..., 56.

20 Sharifuddin, Tabkim vol. X No. 2., ..., 56.

21 Mohd $\mathrm{H}$ \{afiz Jamaludin dan Ahmad Hidayat Buang, Istihsan dalam Penghakiman Mahkamah Syariah di Malaysia, Kanun Julai 2015., 251.

22 Ubaidillah \& Nawawi, “Tinjauan Istihsan terhadap Bai' al-Wafa' dan Implikasi Konsistensi Bermadzhab di Baitul Maal Wa Tamwil Sidogiri Cabang Bondowoso", Istidlal, Volume 1, Nomor 2, Oktober 2017., 119. 
statemen diktum hukum kehujjahannya. Inilah aspek pokok istihsan di mana diktum hukum macam yang kedua berdasarkan maslahah memandang diktum hukum juz'i dari pada diktum hukum kulli.

Dari berbagai ayat dan hadith, terdapat berbagai permasalahan yang apabila diberlakukan hukum sesuai dengan kaidah umum dan qiyas, ada kalanya membawa kesulitan bagi umat manusia. Sedangkan shari'at Islam ditujukan untuk menghasilkan dan mencapai kemaslahatan manusia. Untuk menghilangkan kesulitan itu, maka ia boleh berpaling kepada kaidah lain yang memberikan hukum sesuai dengan kemaslahatan umat.23

Persoalan sebenarnya hanya terletak pada pendefinisian istibsan saja. Sebab, Abu al-Hanifah memang tidak mendeskripsikan istibsan secara detail. Problem utama yang membuat Imam al-Shafi'i tidak sepakat dengan istibsan adalah karena saat ia berdiskusi dengan para pengikut Abu al-Hanifah, mereka tidak mampu menjawab pertanyaan al-Shafi'i tentang alasan penggunaan kata istibsan. Mereka hanya bertaklid kepada Abu al-Hanifah. Sehingga, al-Shafi'i menyimpulkan, bahwa istibsan adalah penetapan hukum sesuai dengan kehendak orang yang melakukannya. Artinya, hal-hal yang dianggap baik oleh orang yang melakukan istibsan, maka itulah yang ditetapkan sebagai hukum, karena demikianlah arti hakikat dari istihsan. Jadi penetapan hukum dengan istihsan menurut Imam alShafi'I, tidak memiliki metode dan semata-mata mengikuti hawa nafsu. 24

\section{Macam-macam Istihsan}

Berdasarkan macam-macam istibsan, peneliti menjabarkan sesuai dengan pendapat Ulama Usul dibawah ini.

Istihsan diketahui ada dua bentuk, yaitu:

1. Istibsan Qiyasi

Istibsan qiyasi terjadi pada suatu kasus yang mungkin diterapkan padanya salah satu dari dua bentuk qiyas jali (qiyas terang-terangan) atau qiyas khafi (qiyas tersembunyi). Pada dasarnya, bila kejelasan 'illat yang dijadikan sebagai standar, maka

23 Ubaidillah \& Nawawi, Istidlal, Volume 1, Nomor 2, ..., 119.

24 Iskandar Usman, Istibsan dan Pembaharuan Hukum Islam, (Jakarta: PT Raja Grafindo Persada, 1994), 7-8. 
qiyas jali lebih tepat untuk didahulukan atas qiyas khafi. Namun bila seorang mujtahid memandang menerapkan qiyas khafi lebih besar kemaslahatannya bagi manusia dari qiyas jali, maka qiyas khafi boleh digunakan, meskipun dengan meninggalkan qiyas jali.

2. Istibsan Istithna'i

Misalnya seorang pembeli memesan barang kepada seorang pembuat atau penjual barang dengan spesifikasi tertentu. Lalu pembuat barang atau penjualnya menyatakan kesanggupan untuk memenuhi pesanan yang diminta. Menurut kalangan Hanafiyyah, melalui pernyataan kedua belah pihak seperti itu berimplikasi telah terjadi juali beli secara sah. Berdasarkan qiyas, juali beli istithna' seperti itu tidak boleh dilakukan karena barang yang menjadi obyek transaksi tidak ada pada saat transaksi berlangsung. Namun, melalui istibsan jual beli secara istithna' dibolehkan karena memang dibutuhkan oleh manusia dalam kehidupannya. Bahkan, bolehnya menggunakan akad istithna' ini didukung oleh ïma' ulama.25

Dikutip Asmawi dalam bukunya Perbandingan Ushul Fiqh, Ibnu al-Arabi membagi istihsan kepada 4 macam, antara lain:

1. Istibsan bi al-Urf (Istibsan dengan Urf)

Imam Malik mengatakan, bahwa mazhabnya meninggalkan dalil umum karena ada 'urf. Contohnya, apabila si B bersumpah tidak akan memasuki rumah maka berdasarkan istibsan dengan men-takhsis keumuman lafal dengan 'urf, masuk masjid tiaklah melanggar sumpah tersebut karena masjid, menurut 'urf tidak dinamakan rumah.26

2. Istibsan bi al-Maslahah (istibsan dengan al-maslabab)

Adapun meninggalkan dalil umum dengan dasar al-maslabah, dicontohkan dengan kasus beban peminjaman buruh yang berkongsi, berdasarkan kaidah al-asl, buruh yang berkongsi merupakan orang yang terpercaya, dan orang yang demikian tidak perlu dibebani penjamin kecuali jika telah tampak jelas kelakuan tidak baik.

25 Ibid., 79.

26 Asmawi, Perbandingan Ushul Fiqh, (Jakarta: AMZAH, 2011), 113. 
Akan tetapi, berdasarkan dalil istibsan, Imam Malik berpandangan bahwa buruh yang berkongsi tersebut tetap dibebani peminjaman dan beliau meninggalkan kaidah al-asl di atas pada masa beliau hidup, di kalangan buruh nyaris hilang rasa tanggungjawab dan marak kelakuan kbianat, dan inilah sisi almaslahah dimaksud. Jadi, al-maslahah ini dijadikan dasar dari pengecualian kaidah al-asl.27

3. Istibsan bi al-Ijma' (istibsan dengan Ijma)

Adapun meninggalkan kaidah umum atau dalil umum dengan dasar ijma', dicontohkan dengan kasus kewajiban orang yang memotong ekor kedelai tunggangan untuk membayar seluruh harta keledai itu. Hal ini dianggap pengecualian dari kaidah umum atau kaidah al-asl karena kaidah umum atau kaidah al-asl menetapkan kewajiban seseorang membayar kerugian sebesar harga yang berkurang dari benda milik orang lain yang rusak yang disebabkan perbuatannya.

Kalau si B memotong ekor keledai tunggangan, dia wajib membayar kerugian sebesar harga yang berkurang dari keledai itu sebagai akibat perbuatannya, inilah kaidah umum atau kaidah alasl tersebut. Akan tetapi, ijma' dirusak sebagian tubuhnya, harus diganti secara keseluruhan. Imam Malik menjadikan ijma' ini sebagai sandaran bagi dalil istihsan terhadap kasus tersebut, yakni si pemotong ekor keledai tunggangan itu harus membayar seluruh harga keledai itu. 28

4. Istibsan dengan Kaidah Raf al-Harj wa al-Mashaqqah

Kaidah raf' al-harj wa al-masyaqqah yakni menghilangkan kesulitan merupakan kaidah yang bersifat qat'i. contohnya, kasus pemakaian kamar mandi umum tanpa ketentuan jumlah harga sewa, lama masa pemakaian, dan jumlah air yang digunakan. Menurut kaidah umum atau kaidah al-asl, kasus demikian dilarang sebab mengandung garar. Berdasarkan istibsan, kasus demikian dibolehkan dengan dasar pertimbangan raf' al-barj wa al-masyaqqah (menghilangkan kesulitan) karena pemakaian kamar mandi 
umum seperti demikian sudah menjadi kebutuhan masyarakat yang tidak bisa dihindari.

Tegasnya, istibsan menurut golongan ulama Malikiyyah tidak keluar dari dalil-dalil shara', sebaliknya, ia justru beramal dengan dalil shara' itu sendiri dan meninggalkan dalil shara' yang lain. Menurut mereka, istibsan pada intinya dalah meninggalkan tuntutan suatu dalil shara' dan beralih kepada tuntutan dalil shara' yang lain.

Dikutip Asmawi dalam karyanya Ibnu al-Arabi mejelaskan bahwa istihsan adalah beramal dengan salah satu dari dua dalil yang lebih kuat. Imam Malik bin Anas men-takhsis dalil umum atau qiyas dengan al-maslahah, dengan dasar pertimbangan, bahwa asl-maslahah itu merupakan salah satu jenis yang diperhatikan shara'. Maka, tidak ada halangan beramal dengan al-maslahah ini meskipun berbeda dengan dalil umum atau qiyas karena yang bertentangan dengan dalil umum atau qiyas ini pada hakikatnya adalah serangkaian nas yang mendukung al-maslahah.29 lain:

Ulama Hanafiyyah membagi istibsan kepada 6 macam, antara

1. Istihsan bi al-Nass (istihsan berdasarkan ayat atau hadis).

Maksudnya, ada ayat atau hadis tentang hukum suatu kasus yang berbeda dengan ketentuan kaidah umum.30 Pada dasarnya, kaidah umum (al-qawa'id al-kulliyah) sudah menaungi masalahmasalah semakna yang dicakupnya, tetapi pada kenyataannya terdapat nas spesifik yang menetapkan hukum masalah tertentu dari masalah-masalah semakna yang dicakup kaidah umum itu, yang berbeda dengan hukum yang ditarik dari kaidah umum tersebut. 31

Misal istibsan dengan Sunnah Rasul adalah dalam kasus orang yang makan dan minum karena lupa ketika ia sedang puasa. Menurut kaidah umum (qiyas), puasa orang ini batal karena ia telah memasukkan sesuatu ke dalam kerongkongannya dan tidak menahan puasanya sampai berbuka.

29Ibid., 114.

30 Nasrun Haroen, Ushul Figh I, (Jakarta: Logos, 1996), 105.

31 Asmawi, Perbandingan Ushul Figh, ..., 144. 
2. Istibsan bi al-Ijma' (istihsan yag didasarkan kepada ijma')

Misalnya adalah dalam kasus pemandian umum. Menurut ketentuan kaidah umum, jasa pemandian umum itu harus jelas, yaitu berapa lama seseorang mandi dan berapa jumlah air yang ia pakai. Akan tetapi, apabila hal ini dilakukan maka akan menyulitkan bagi orang banyak. Oleh sebab itu, para ulama sepakat menyatakan bahwa boleh mempergunakan jasa pemandian umum, sekalipun tanpa menentukan jumlah air dan lama waktu yang terpakai.32

3. Istibsan bi al-Qiyasal-Khafiy (istibsan berdasarkan qiyas yang tersembunyi).

Misalnya, dalam masalah wakaf lahan pertanian. Menurut ketentuan qiyas jaliy (qiyas yang nyata), wakaf ini sama dengan jual beli, karena pemilik lahan telah menggugurkan hak miliknya dengan memindahtangankan lahan tersebut. Oleh sebab itu, hak orang lain untuk melewati tanah tersebut atau hak orang lain untuk mengalirkan air ke lahan pertaniannya melalui tanah tersebut, tidak termasuk dalam akad wakaf itu, kecuali jika dinayatakan dalam akad. Menurut qiyas al-khafiy (qiyas yang tersembunyi) wakaf itu sama dengan menyewa, karena maksud dari wakaf adalah memanfaatkan lahan pertanian yang diwakafkan. Dengan sifat ini, maka seluruh hak orang lain yang telah ada di lahan pertanian tersebut, seperti hak melewati lahan pertanian itu atau hak mengalirkan air di atas lahan pertanian tersebut, termasuk ke dalam akad wakaf, sekalipun tidak dijelaskan dalam akad. Apabila seorang mujtahid mengambil hukum kedua (qiyas al-khafiy), maka ia disebut berdalil dengan istibsan.33

4. Istihsan bi al-Maslahah (istibsan berdasarkan kemaslahatan)

Misalnya, ketentuan umum menetapkan bahwa buruh di suatu pabrik tidak bertanggungjawab atas kerusakan hasil komoditi yang diproduk pabrik tersebut, kecuali atas kelalaian dan kesengajaan mereka, karena mereka hanya sebagai buruh yang menerima upah. Akan tetapi, demi kemaslahatan dalam

32 Nasrun Haroen, Ushul Fiqh I, .., 105.

33 Ibid., 106. 
memelihara harta orang lain dari sikap tidak bertanggungjawab para buruh dan sulitnya mempercayai sebagian pekerja pabrik dalam masalah keamanan produk, maka ulama Hanafiyyah menggunakan istibsan dengan menyatakan bahwa buruh harus bertanggungjawab atas kerusakan setiap produk pabrik itu, baik disengaja maupun tidak.

Ulama Malikiyyah mencontohkannya dengan kebolehan dokter melihat aurat wanita dalam berobat. Menurut kaidah umum (qiyas), seseorang dilarang melihat aurat orang lain. Tetapi, dalam keadaan tertentu seseorang harus membuka bajunya untuk didiagnosa penyakitnya, maka untuk kemaslahatan diri orang itu, menurut kaidah istibsan seorang dokter boleh melihat aurat wanita yang berobat kepadanya.

5. Istibsan bi al-'Urf (istibsan berdasarkan adat kebiasaan yang berlaku umum)

Contohnya sama dengan contoh istibsan yang berdasarkan ijma' nomor 2 di atas, yaitu dalam masalah pemandian umum yang tidak ditentukan banyak air dan lama pemandian itu digunakan oleh seseorang, karena adat kebiasaan setempat bisa dijadikan ukuran dalam menentukan lama dan jumlah air yang terpakai.

6. Istibsan bi al-Dharurah (istihsan berdasarkan keadaan darurat)

Artinya, ada keadaan-keadaan darurat yang menyebabkan seorang mujtahid tidak memberlakukan kaidah umum atau qiyas. misalnya dalam kasus sumur yang kemasukan najis. Menurut kaidah umum, sumur itu sulit untuk dibersihkan dengan mengeluarkan seluruh air dari sumur tersebut, karena sumur yang sumbernya dari mata air, sulit untuk dikeringkan. Akan tetapi, ulama Hanafiyyah mengatakan bahwa dalam keadaan seperti ini, untuk menghilangkan najis tersebut cukup dengan memasukkan beberapa gallon air ke dalam sumur itu, karena keadaan darurat menghendaki agar orang tidak mendapatkan kesulitan dalam mendapatkan air untuk beribadah dan kebutuhan hidupnya.34

Pembagian istihsan menurut madzhab Maliki, antara lain:

1. Istibsan dengan al-Urf

34 Ibid., 107. 
Contoh yang dikemukakan oleh madzhab Maliki terhadap istihsan ialah seseorang yang bersumpah tidak akan makan daging kalau ia makan daging ikan, maka tidaklah dianggap melanggar sumpah walaupun di dalam Alquran dijelaskan bahwa ikan sama dengan daging. 35

2. Istihsan dengan al-Maslabah

Istibsan jenis ini ialah istibsan yang disandarkan pada kemaslahatan.36 Dalam artian mengenyampingkan pemberlakuan ketentuan hukum qiyas karena pertimbangan maslabah yang lebih penting. Contoh, jika seorang menyewa barang, kemudian barang tersebut rusak bukan kesalahan penyewa, maka menurut ketentuan qiyas penyewa tidak menanggung resiko atas kerusakan tersebut. Akan tetapi, ketentuan ini tidak berlaku, karena demi kemaslahatan penyewa dituntut untuk mengganti atas kerusakan. 37

3. Istibsan dengan Raf'ul Haraj

Yang dimaksud dengan istihsan ini ialah istihsan yang disandarkan pada menghindari kesulitan yang dihadapi.38Istibsan jenis ini sebenarnya tidak beda jauh dengan istibsan pada jenis kedua, namun istibsan jenis ini berkisar pada masalah muamalah dan ibadah.

Contoh yang berhubungan dengan ibadah, jika seseorang melakukan ibadah puasa (senin, kamis) karena terbiasa kemudian pada suatu hari ketika melaksanakan puasa sunnah (senin, kamis) ia sakit dan akhirnya ia meninggalkan puasa sunnah tersebut demi kesehatan jasmani.39

\section{Alat Bukti Saksi dalam Hukum Islam dan Hukum Positif}

1. Pengertian Saksi

a. Menurut Fiqih

35 Romli, Studi Perbandingan Ushul Fiqh, (Yogyakarta: Pustaka Pelajar, 2014), 206.

36 Kasjim Salenda, Jurnal Kebujjahan Istibsan dan Implikasinya dalam Istimbat Hukum, (al-daulah: 2013), 11.

37 Romli, Studi Perbandingan Ushul Fiqh, ...., 207.

38 Kasjim Salenda, Jurnal Kebujjahan Istibdan dan Implikasinya dalam Istimbat Hukum, 11.

39 Romli, Studi Perbandingan Ushul Figh, ...., 208. 
Saksi berasal dari kata syahid (orang yang menyaksikan), yaitu memberitahukan tentang apa yang disaksikan dan dilihatnya. Maknanya ialah pemberitahuan seseorang tentang apa yang dia ketahui.

b. Menurut Hukum Positif

Saksi merupakan orang yang memberikan keterangan di muka sidang, dengan memenuhi syarat-syarat tertentu, tentang suatu peristiwa atau keadaan yang ia lihat, dengar dan ia alami sendiri, sebagai bukti terjadinya peristiwa atau keadaan tersebut.40

2. Syarat Seseorang Menjadi Saksi

a. Menurut Fiqih

Syarat merupakan suatu kewajiban yang harus di miliki seseorang untuk memberikan kesaksian, sehingga apanila tidak terpenuhinya syarat-syarat maka kesaksian seseorang tidak dapat diterima. Adapun syarat-syarat saksi menurut Hukum Islamadalah sebagai berikut:

1) Islam

Orang yang tidak memeluk agama Islamtidak diterima menjadi saksi untuk orang Islam.

2) Baligh

Minimal 15 tahun, anak-anak yang belum sampai umur tidak diterima menjadi saksi. Firman Allah Swt.

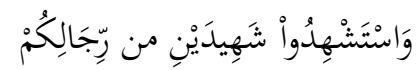

"Dan persaksikanlah dengan dua orang saksi dari orang-orang lelaki di antaramu".

3) Berakal

Orang yang tidak berakal sudah tentu tidak dapat di percaya.

4) Merdeka

Hamba sahaya tidak dapat di terima menjadi saksi karena saksi di serahi kekuasaan, sedangkan hamba sahaya tidak dapat di serahi kekuasaan.

5) Adil

40 Mukti Arto, Praktek Perkara Perdata Pada Pengadilan Agama, (Jogjakarta: Pustaka Pelajar, 1996), 160. 
Orang yang adil ialah yang memiliki sifat:

a) Menjauhi segala dosa besar, tidak terus - menerus mengerjakan dosa kecil.

b) Baik hati

c) Dapat dipercaya sewaktu marah, tidak akan melanggar kesopanan.

d) Menjaga kehormatannya sebagaimana kehormatan orang yang setingkat dengan dia.41

b. Menurut Hukum Positif

Syarat saksi menurut Hukum Perdata harus memenuhi syarat formil dan materiil.42

Syarat formil saksi ialah:

1) Berumur 15 tahun ke atas;

Anak-anak yang belum mencapai umur 15 tahun (pasal 145 ayat 1 sub 3 Jo. Ayat 4 HIR, pasal 172 ayat 1 sub 5 Rbg clan 1912 BW), boleh di dengar, akan tetapi tidak sebagai saksi. Keterangannya hanyalah boleh dianggap sebagai penjelasan belaka, untuk memberi keterangan tersebut mereka tidak perlu disumpah (pasal 145 ayat 4 HIR dan pasal $173 \mathrm{Rbg}$ ).

2) Sehat akalnya

Orang gila, meskipun kadang-kadang ingatannya terang atau sehat tidak boleh didengar sebagai saksi, karena mereka dianggap tidak cakap dalam memberikan kesaksian. Hal ini diatur dalam pasal 145 ayat 1 sub 4 HIR, 172 ayat 1 sub 5 Rbg dan 1912 BW.

3) Tidak ada hubungan keluarga sedarah dan keluarga semenda dari salah satu pihak menurut keturunan yang lurus, kecuali undang-undang menentukan lain;

Alasan pembatasan ini ialah, bahwa mereka (keluarga semenda) pada umumnya dianggap tidak cukup obyektif apabila didengar sebagai saksi, untuk itu menjaga kekeluargaan yang baik, serta untuk mencegah timbulnya tekanan bathin setelah memberi keterangan.

41 Sulaiman Rasyid, Fiqh Islam (Bandung: Sinar Baru Algensindo, 2000), 490. 42 Mukti Arto, Praktek Perkara Perdata Pada Pengadilan Agama, ..., 161. 
Akan tetapi menurut pasal 145 ayat $2 \mathrm{HIR}$, pasal 172 ayat 2 Rbg dan 1910 alinea 2 BW, mereka ini tidak boleh ditolak sebagai saksi dalam perkara perdata yang menyangkut kedudukan keperdataan dari para pihak atau dalam perkara yang menyangkut perjanjian kerja.

4) Tidak ada hubungan perkawinan dengan salah satu pihak meskipun sudah bercerai

Suami istri dalam satu pihak, meskipun sudah bercerai tidak boleh membrikan keterangan sebagai saksi satu sama lain. Hal ini diatur dalam pasal 145 ayat 1 sub 2 HIR, 172 ayat 1 sub 3 Rbg dan 1910 alinea 1 BW.

5) Tidak ada hubungan kerja dengan salah satu pihak dengan menerima upah

Hal ini dijelaskan dalam pasal 144 ayat 2 HIR, kecuali Undang-undang menentukan lain.

6) Menghadap di persidangan

Kewajiban untuk menghadap di persidangan pengadilan yang di simpulkan dari pasal 140 dan 11 HIR atau pasal 166, $167 \mathrm{Rbg}$, menentukan adanya sanksi bagi saksi yang tidak mau datang setelah di panggil secara patut.

7) Mengangkat sumpah menurut agamanya

Sebelum memberi keterangan para saksi harus di sumpah menurut agamanya (pasal $147 \mathrm{HIR}$, pasal $175 \mathrm{Rbg}$ dan 1911 KUH Perdata jo. Pasal 4 S 1920 No. 69). Oleh karena sumpah ini diucapkan sebelum memberi kesaksian dan berisi janji untuk menerangkan yang sebenar-benarnya , maka sumpah itu juga disebut sumpah promisior, lain halnya sumpah sebagai alat bukti disebut sumpah confimatior. Sumpah oleh saksi ini harus diucapkan di hadapan kedua belah pihak di persidangan.

\section{Pertimbangan Hakim Tentang Saksi Non Muslim Pada Perkara Perceraian Dalam Putusan Nomor. 1889/Pdt.G/2017/PA.Sda}

Dalam pertimbangan hukum yang termuat dalam putusan Pengadilan Agama Sidoarjo Nomor. 1889/Pdt.G/2017/PA.Sda, bahwa pada hari sidang yang telah ditentukan Pemohon dan Termohon hadir di persidangan. Majelis Hakim telah berusaha 
mendamaikan kedua belah pihak namun tidak berhasil. Majelis Hakim memerintahkan kepada para pihak untuk menempuh mediasi. Namun berdasarkan surat pemberitahuan dari Nurul Huda, S.H.I., Mediator pada Pengadilan Agama Sidoarjo tertanggal 25 Juli 2017, pokoknya menyatakan mediasi antara para pihak tidak berhasil.

Sesuai dengan pernyataan yang ada, Pemohon telah menikah dengan Termohon berdasarkan Hukum Islam. Karena sering terjadi pertengkaran, Pemohon menuntut agar Pengadilan Agama Sidoarjo memberi izin kepada Pemohon untuk menjatuhkan talak satu raj'i terhadap Termohon di depan sidang Pengadilan Agama Sidoarjo, karena berdasarkan pasal 39 Undang-undang Nomor 1 tahun 1974 tentang Perkawinan Jo Pasal 66 ayat (1) Undang-undang Nomor 7 tahun 1989 tentang Peradilan Agama, Pemohon mempunyai legal standing untuk mengajukan permohonan perceraian tersebut.

Berdasarkan pertimbangan-pertimbangan di atas dan karena permohonan Pemohon telah memenuhi syarat formal suatu permohonan maka terhadap petitum permohonan Pemohon secara formal dapat diterima untuk diperiksa.

Bahwa yang menjadi pokok permohonan Pemohon adalah agar Pengadilan Agama Sidoarjo memberi izin kepada Pemohon untuk menjatuhkan talak satu raj'i terhadap Termohon di depan sidang Pengadilan Agama Sidoarjo dengan alasan antara Pemohon dan Termohon sering terjadi perselisihan dan pertengkaran. Pertengkaran terjadi karena antara Pemohon Termohon tidak ada kecocokan lagi, masalah kecil jadi percekcokan dan Termohon sering keluar rumah tanpa pamit Pemohon. Termohon mau pulang ke Jakarta dan Pemohon telah menjatuhkan talak kepada Termohon. Akhirnya, sejak bulan Maret 2017, Pemohon dan Termohon masih satu rumah tetapi tidak tidur bersama. Antara Pemohon dan Termohon sekarang telah pisah ranjang selama 3 bulan dan meskipun telah ditempuh upaya damai, tetapi tidak berhasil.

Atas permohonan Pemohon tersebut Termohon memberikan jawaban yang pokoknya membenarkan, bahwa antara Pemohon dan Termohon sering terjadi perselisihan dan pertengkaran dan 
Termohon juga membenarkan penyebabnya serta tidak keberatan bercerai dengan Pemohon.

Dengan demikian, bahwa pengakuan Termohon termasuk pengakuan berkualifikasi yang berdasarkan pasal 176 HIR Jo. pasal 163 HIR, serta dengan memperhatikan prinsip menegakkan kebenaran dan keadilan ( to enforce the truth and justice), dan juga untuk memenuhi ketentuan pasal 76 Undang-undang nomor 7 tahun 1989 Jo. pasal 22 Peraturan Pemerintah nomor 9 tahun 1975, Majelis berpendapat, bahwa Pemohon wajib membuktikan dalil permohonannya.

Untuk membuktikan dalil-dalilnya Pemohon maka pemohon telah mengajukan alat bukti tertulis yakni P-1 dan P-2 serta saksi Pemohon I dan saksi II yang selengkapnya akan dipertimbangkan lebih lanjut. P-1 dan P-2 merupakan akta otentik yang dikeluarkan oleh pejabat yang berwenang, bermaterai cukup dan cocok dengan aslinya, oleh karena itu akta tersebut berdasarkan pasal 165 HIR / 1868 KUH Perdata, memiliki nilai pembuktian sempurna dan mengikat.

Sesuai dengan keterangan saksi-saksi Pemohon dan Termohon tersebut memenuhi syarat-syarat formal sebagai saksi berdasarkan pasal 76 Undang-undang nomor 7 tahun 1989 tentang Peradilan Agama Jo. Pasal 171 HIR jo. Pasal 22 Peraturan Pemerintah nomor 9 tahun 1975, maka sepanjang mengenai sesuatu yang dilihat sendiri dan atau dialami sendiri, keterangan saksi tersebut bernilai sebagai alat bukti yang sah dan dapat diterima sebagai alat bukti.43

Bahwa atas dasar tuntutan yang dikemukakan Pemohon dan berdasarkan bukti-bukti yang diajukan Pemohon, majelis Hakim akan mempertimbangkan tuntutan Pemohon sebagaimana terurai dalam surat permohonan Pemohon petitum angka 2 yaitu:

Berdasarkan bukti P.1 serta berdasarkan keterangan saksi-saksi Pemohon dan Termohon yang saling bersesuaian, telah terbukti bahwa Pemohon dan Termohon adalah suami Istri yang menikah berdasarkan Hukum Islam, oleh karenanya maka terbukti secara sah menurut hukum bahwa Pemohon dan Termohon adalah suami istri, setelah menikah Pemohon dan Termohon tinggal bersama dalam

$\begin{array}{lllll}43 \text { Direktori Putusan Pengadilan Agama } & \text { Sidoarjo Nomor. } \\ \text { 1889/Pdt.G/2017/PA.Sda. } & & & & \end{array}$


satu rumah tempatnya di Kecamatan Waru Kabupaten Sidoarjo kemudian pindah di Kecamatan Taman Kabupaten Sidoarjo dan telah hidup layaknya suami istri namun belum dikaruniai anak.

Berdasarkan informasi yang peneliti dapatkan melalui wawancara kepada salah satu majelis hakim yang memeriksa perkara ini di Pengadilan Agama Sidoarjo, Mohamad Jumhari hakim Pengadilan Agama Sidoarjo mengemukakan, bahwa Perdebatan tentang saksi muslim dan non-muslim itu sudah cukup lama, seiring dengan perdebatan tentang kedudukan hakim perempuan. Undangundang kita, tahun 1989 nomor 7, sebelum itu sudah terjadi perdebatan, tentang kedudukan hakim perempuan dan saksi nonmuslim.44

Dari perdebatan itu menjadi satu pemahaman bahwa Hakim perempuan tidak menjadi masalah, madzhabnya yang dipakai adalah madzhab Hanafi, kalau madzhab syafi'i itu Hakim perempuan tidak diperbolehkan. Kemudian tentang saksi non-muslim juga terjadi perbedaan madzhab, kita ambil pendapatnya lebih cenderung non imam syafi'i, maka itu sudah cukup lama dan sudah tidak lagi menjadi ikhtilaf karena sudah terjadi lama sebelum berlakunya Undang-Undang Nomor 7 Tahun 89 Tentang Peradilan Agama.

\section{Analisis Istihsan terhadap Pertimbangan Hakim tentang Saksi Non Muslim pada Perkara Perceraian dalam Putusan Nomor. 1889/Pdt.G/2017/PA.Sda}

Indonesia adalah negara yang berkarakter majemuk (Pluralitas) sehingga masyarakatnya sangat dianjurkan memiliki sikap tenggang rasa dan saling menghargai dalam perbedaan. Banyak sekali suatu persoalan yang menimbulkan konflik dalam masyarakat disebabkan karena kemajemukan tersebut. Karena berbagai macam konflik yang terjadi di dalam kehidupan bermasyarakat tersebut, maka harus ada solusi agar terwujud keselarasan, tercipta kedamaian dan keadilan tersebut mendapatkan keberhasilan yang diharapkan, tentu bergantung pada asas hukum dalam pemerintah dan system Peradilan, salah satunya adalah saksi dalam proses pembuktian.

Begitu pentingya peran pembuktian dengan kesaksian, hampir semua proses pemeriksaan perkara selalu terdapat kesaksian.

44 Mohamad Jumhari, Wawancara, Tanggal 16 Mei 2018. 
Kesaksian tersebut digunakan untuk menguatkan bukti yang dikemukakan guna memutuskan perkara perdata dalam Peradilan Agama.

Mengenai saksi banyak dijumpai perbedaan pendapat di kalangan fuqaha, ada kriteria-kriteria tertentu untuk bisa menjadi saksi dalam persidangan, seperti yang menyangkut persoalan agama. Maka dalam konteks ini saksi menjadi masalah penting terutama berkaitan dengan adil atau tidaknya saksi yang digunakan.

Adapun kesaksian non-muslim tidak diperbolehkan secara mutlak, hal ini mengambil dalil dari firman Allah QS. Ath-Thalaq (potongan ayat 2):

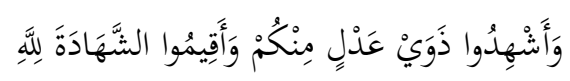

Dan hendaklah kamu persaksikean (yang demikian) kepada dua orang saksi yang adil di antaramu dan hendaklah kamu tegakkan kesaksian karena Allah.

Sesungguhnya Allah mensifatkan mereka (non-muslim) sebagai orang yang dusta dan fasik, sedangkan orang yang fasik dan dusta tidak dapat diterima kesaksiannya. Menurut Mahmud Syathut dalam bukunya Fiqih Tujuh Madð̧ab, sesungguhnya menerima kesaksian mereka berarti memuliakan mereka dan mengangkat derajat mereka, sedangkan hinanya kekufuran mereka menghalangi kita memuliakan mereka dan mengangkat derajat mereka.45

Dari kesimpulan ayat tersebut, kesaksian non-muslim tidak diperbolehkan, karena bersifat temporer, sesuai dengan situasi dan kondisi maka hal ini dapat berubah berdasarkan kaidah:

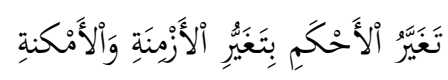

Perubahan hukum tergantung dengan perubahan waktu dan tempatnya

Hal ini senada dengan apa yang diatur menurut hukum acara umum, bahwa dalam pemeriksaan saksi berlaku asas umum hakim tidak boleh menerima suatu hal sebagai kenyataan yang dikemukakan oleh saksi selama ia belum yakin benar tentang kebenaran yang disampaikan oleh saksi tersebut. Akan tetapi, hakim

45 Mahmud Syalthut, Fiqib Tujuh Maḑ̌hab, (Bandung : 2000) 256-256. 
juga harus mempercayai saksi-saksi dengan penuh keyakinan, agar hal ini terlaksana dengan baik maka hakim harus memperhatikan dengan seksama cara hidup saksi-saksi yang diajukan.

Oleh karena itu muncul persoalan apakah saksi non muslim itu dapat digunakan sebagai alat bukti dalam masalah perdata jika ditinjau dari bingkai istibsan.

Istihsan adalah segala sesuatu yang di anggap baik, baik menurut 'urf/adat. Secara hukum Islam, bahwa syarat-syarat saksi disebutkan antara lain: Islam, baligh, berakal, merdeka, dan adil. Berdasarkan hukum Islam disebutkan, bahwa saksi itu harus Islam. tetapi sesuai dengan perkembangan yang sekarang, hidup sudah membaur, mungkin saja tetangga kiri kanannya non-muslim dan yang mengetahui perkara tersebut adalah orang non-muslim, dan juga ketika diharuskan mencari saksi yang beragama Islam, maka para pencari keadilan akan kesulitan.

Karena istibsan adalah ketetapan dari dua dalil yang daripadanya lebih kuat dan mengambil yang lebih besar kemaslahatannya, maka dari pertimbangan hakim yang termuat dalam putusan tersebut kurang tepat menurut peneliti, karena tidak memutuskan sesuai dengan hukum Islam. Putusan tersebut seharusnya mempertimbangkan antara hukum acara dengan hukum Islam, sehingga lebih jelas dalam pertimbangannya. Jikalau mempertimbangkan kedua dalil, maka saksi muslim ataupun saksi non-muslim akan lebih kelihatan lmana yang ebih besar maslahatnya dalam mengungkap kebenaran peristiwa.

Bila melihat teori pembagian istibsan, maka adanya kesaksian non-muslim pada perkara perceraian tergolong istibsan qiyasi, istibsan bi al-maslabah, istibsan bi raf' al-harj wa al-mashaqqah, istibsan bi aldharurah. Disebut istibsan qiyasi karena saksi non-muslim selaku saudara kandung dari para pihak dan juga yang mengetahui keseharian para pihak tersebut. Disebut istibsan bi al-maslahab karena untuk kemaslahatan para pihak yang berperkara walaupun saksi tersebut bukan muslim tetapi saksi non-muslim lah yang mengetahui perkara. Sejalan dengan istibsan bi raf' al-harj wa al-mashaqqah yakni menghilangkan kesulitan dengan menghadirkan saksi non-muslim karena untuk mencari saksi muslim yang lebih mengetahui perkara belum tentu kesaksiannya lebih baik daripada kesaksian non- 
muslim. Selanjutnya disebut istibsan bi al-dharurah karena dalam keadaan darurat dan yang mengetahui perkara adalah saksi nonmuslim, maka saksi tersebut diterima kesaksiannya.

Berdasarkan hal di atas, maka adanya kesaksian non-muslim pada perkara perceraian merupakan sesuatu yang dianggap baik. Dengan begitu, kesaksian non-muslim dalam bingkai istibsan karena mengedepankan kemaslahatan, diperbolehkan dalam pembuktian sidang Pengadilan Agama.

\section{Penutup}

Kesaksian non-muslim dalam pemeriksaan sidang di Pengadilan Agama Sidoarjo di pandang sah. Pertama, karena para saksi Pemohon dan Termohon telah memenuhi syarat formal sebagai saksi berdasarkan pasal 76 Undang-Undang Nomor 7 Tahun 1989 Tentang Peradilan Agama jo. pasal 171 HIR jo. pasal 22 Peraturan Pemerintah Nomor 9 Tahun 1975, maka sepanjang mengenai sesuatu yang dilihat sendiri dan atau dialami sendiri, maka keterangan saksi tersebut bernilai sebagai alat bukti yang sah dan dapat diterima sebagai alat bukti.

Kedua, karena perbedaan madzhab sekarang sudah tidak dipakai lagi dalam kedudukan saksi perceraian. Selama memenuhi pasal 22 Peraturan Pemerintah nomor 9 tahun 1975 tentang aturan pelaksana dari Undang-Undang Nomor 1 Tahun 1974 yang mengatur perkawinan muslim dan non-muslim di dalamnya, maka tidak menjadi masalah.

Berdasarkan istibsan, kesaksian non-muslim diperbolehkan, pertama, karena ini persoalan kesetaraan, maka saksi tidak lagi mempersoalkan agama, oleh karenanya baik saksi muslim maupun non-muslim selama saksi itu memberikan keterangan di bawah sumpah, maka keterangan saksi di anggap sah dan saksi no- muslim di perbolehkan. Kedua, dalam perkembangan kehidupan bermasyarakat pada saat ini sudah membaur, katakanlah tetangga kanan kiri non-muslim dan ketika tidak ada saksi muslim para pihak akan merasa kesulitan.

\section{Daftar Pustaka}

A. Hanafie. Usul Fiqh, Jakarta: Widjaya, 1989. 
Abdul Manan. Penerapan Hukum Acara Perdata di Lingkungan Peradilan Agama, Jakarta: Prenada Media, 2005.

Ahmad Ro'iat. 'Kesaksian Non Muslim dalam Sidang Peradilan Agama Studi Komparatif Antara Mazhab Hanafi dan Mazhab Syafi'i,' Skripsi-UIN Sunan Kalijaga, Yogyakarta, 2005.

Ahmad Roikan. 'Kesaksian Non Muslim Sebagai Alat Bukti Dalam Perkara Perceraian di Pengadilan Agama Boyolali', SkripsiSTAIN Salatiga, 2013.

Amir Syarifuddin. Hukum Perkawinan Islamdi Indonesia Antara Fiqh Munakahat dan Undang-undang Perkawinan, Ed. 1, Cet. Ke-2, Jakarta: Prenada Media, 2006.

Andi Nur Alamsyah. 'Kedudukan Saksi Non Muslim Dalam Praktik Hukum Acara di Lingkungan Peradilan Agama', SkripsiUniversitas Hasanuddin, Makassar, 2014.

Eka Sakti Habibullah, "Pandangan Imam Abu Hanifah dan Imam Shafi'i tentang al-Istihsan", Al Mashlahah Jurnal Hukum dan Pranata Sosial Islam, 453.

Firdaus. Usul Fiqih, Jakarta: Zikrul, 1999.

Ibnu Elmi AS Pelu dan Abdul Helim. Konsep Kesaksian "Hukum Acara Perdata di Peradilan Agama Islam", Malang: Setara Press, 2015.

Imam Taqiyyudin. Kifayatul Akhyar, Beirut: Darul Fikri, 1994.

Iskandar Usman. Istibsan dan Pembaharuan Hukum Islam, Jakarta: PT Raja Grafindo Persada, 1994.

Lajnah Pentashihan Mushaf Al-Qur'an. Al-Qur'an Dan Terjemabnya, Jakarta Selatan: PT. Hati Emas, 2007.

Mohammad Roviqi. Pertimbangan Hakim Tentang Kedudukan Saksi Non Muslim Dalam Perkara Perceraian di Pengadilan Agama Kabupaten Bangli Provinsi Bali. Studi Atas Perkara No. 01/Pdt.G/2006/PA. Bangli. Skripsi-UIN Maulana Malik Ibrahim, Malang, 2011.

Mohd Hafiz Jamaludin dan Ahmad Hidayat Buang, Istihsan dalam Penghakiman Mahkamah Syariah di Malaysia, Kanun Julai 2015.

Muhamad Ma'sum Zainy al-Hasyimiy. Ilmu Ushul Figh, cet.1, Jombang: Darul Hikmah, 2008. 
Muhammad ibn Idris al-Syāfi'i. al-Um, Juz 7, Beirut: Dār al-Ma'rifah. Muhammad Ma'sum Zein, Ilmu Usul Figh, Jombang: Darul Hikmah dan Maktabah al-Syarifah al-Khadijah, 2008.

Nurfitriani Aziz. 'Status Saksi Non Muslim di Peradilan Agama Studi Perbandingan Ibnu Qayyim dan Hukum Acara Perdata', Skripsi-UIN Alauddin, Makassar, 2015.

Sharifuddin. "istihsan dan Pembaharuan Hukum Islam", Tabkim vol. X No. 2, Desember 2014.

Soemiyati. Hukum Perkawinan IslamDan Undang-undang Perkawinan, Yogyakarta: Liberty, 1982.

Ubaidillah \& Nawaw. 'Tinjauan Istihsan terhadap Bai' al-Wafa' dan Implikasi Konsistensi Bermadzhab di Baitul Maal Wa Tamwil Sidogiri Cabang Bondowoso", Istidlal, Volume 1, Nomor 2, Oktober 2017.

Yayan Sopyan. Tarikh Tasyri', Depok: Gramata Publishing, 2010.

Asmawi. Perbandingan Ushul Fiqh, Jakarta: AMZAH, 2011.

Nasrun Haroen. Ushul Figh I, Jakarta: Logos, 1996.

Romli, Studi Perbandingan Ushul Figh, Yogyakarta: Pustaka Pelajar, 2014.

Kasjim Salenda. Jurnal Kebujjahan Istihsan dan Implikasinya dalam Istimbat Hukum, al-daulah: 2013.

Kasjim Salenda, Jurnal Kehuijaban Istibdan dan Implikasinya dalam Istimbat Hukum, 11.

Mukti Arto. Praktek Perkara Perdata Pada Pengadilan Agama, Jogjakarta: Pustaka Pelajar, 1996.

Sulaiman Rasyid. Figh Islam, Bandung: Sinar Baru Algensindo, 2000. Mahmud Syalthut. Fiqib Tujuh Madz̧bab, Bandung : 2000.

Mohamad Jumhari. Wawancara, Tanggal 16 Mei 2018.

Direktori Putusan Pengadilan Agama Sidoarjo Nomor. 1889/Pdt.G/2017/PA.Sda. 